\title{
A HISTORY OF JÖKULHLAUPS FROM STRANDLINE LAKE, ALASKA, U.S.A.
}

\author{
By MATTHEW STURM and CARL S. BENSON
}

(Geophysical Institute, University of Alaska, Fairbanks, Alaska 99701, U.S.A.)

\begin{abstract}
Jökulhlaups, also known as outburst floods, have occurred every 1 to 5 years from Strandline Lake, one of the largest glacier-dammed lakes in North America. The development of a distinct calving embayment in the lobe of Triumvirate Glacier which dams the lake, as well as the filling of a number of supraglacier pools, appear to be reliable precursors to a jökulhlaup. Analysis of contour maps made from photographs taken immediately before and after the jökulhlaup of 17 September 1982 indicate that over 95\% of the lake drains, a volume of approximately $7 \times 10^{8} \mathrm{~m}^{3}$ of water. The glacier lobe which dams the lake fractures and subsides during a jökulhlaup, indicating that the release mechanism is hydrostatic lifting of the ice off of a subglacial spillway. Evidence from the ice-free margins of the glacier suggests that the spillway may be controlled by bedrock. Large variation in the refilling period of Strandline Lake indicates that the subglacial drainage tunnels can remain open for as much as a few years after a jökulhlaup, before they become sealed by sediments and/or glacier ice.
\end{abstract}

RÉSUMÉ. Histoire des vidanges sous-glaciares $d u$ Strandline Lake, Alaska, U.S.A. Des vidanges brutales du Strandline Lake, un des plus grands lacs de barrage glaciaire à vidange périodique et brutale d'Amérique du Nord, se produisent tous les 1 à 5 ans. La vidange catastrophique est précédée par le développement d'un golfe de vêlage dans le lobe du Triumvirate Glacier qui barre le lac ainsi que par le remplissage d'un grand nombre de petits lacs sur le glacier. L'analyse des cartes dressées par photogrammétrie immédiatement avant et après la vidange du 17 septembre 1982 montre que plus de $95 \%$ du volume du lac est évacué, soit environ $7 \times 10^{8} \mathrm{~m}^{3}$ d'eau. Le lobe du glacier qui barre le lac se fracture et s'affaisse pendant la vidange ce qui signifie que cette dernière est due à un soulèvement hydrostatique des $180 \mathrm{~m}$ de glace libérant un déversoir

\section{INTRODUCTION}

The Icelandic term "jokulhlaup" refers to a flash flood produced when water trapped within or behind a glacier is suddenly released; the phenomenon is also called a glacieroutburst flood. Jokkulhlaups may be caused by the release of a water reservoir produced beneath a glacier by geothermal heat or by the break-out of a glacier-dammed lake. Most Alaskan jökulhlaups are of this latter kind. Jökulhlaups are characterized by extremely high discharges over short time periods. The discharge increases exponentially with time because drainage tunnels in the ice increase in diameter as their walls are melted by the dissipation of potential energy from the flowing water (Mathews, 1973; Björnsson, 1974, 1976; Nye, 1976).

This paper deals with jökulhlaups from glacier-dammed Standline Lake; it is based on detailed analysis of topographic maps made from vertical aerial photographs taken immediately before and after the jokkulhlaup of 17 September 1982, together with field observations and historical records, including eye-witness accounts of jökulhlaups since 1940. Strandline Lake, currently one of the largest active glacier-dammed lakes in North America sous-glaciaire. Des évidences apparentes sur les bords libres de glace suggèrent que le déversoir peut être contrôlé par le lit rocheux. De grandes variations dans la durée de remplissage du Strandline Lake indique que les tunnels de drainage sous glaciaires peuvent rester ouverts pendant quelques années à la suite d'une vidange, avant d'être obstrués par des sédiments et/ou de la glace provenant du glacier.

ZuSAMMENFASSUNG. Ablauf von Gletscherläufen aus dem Strandline Lake, Alaska, U.S.A. Gletscherläufe, auch als Ausbruchsfluten bekannt, traten aus dem Strandline Lake, einem der grössten Gletscherlaufseen in Nordamerika, alle 1-5 Jahre auf. Die Entwicklung einer bestimmten Einbuchtung durch Kalbung in der Zunge des Triumvirate Glacier, der den See abdämmt, und die Auffüllung einer Anzahl von Wannen auf der Gletscheroberfläche scheinen die untrüglichen Vorläufer eines Gletscherlaufes zu sein. Die Analyse von Höhenlinienkarten, hergestellt aus photographischen Aufnahmen unmittelbar vor und nach dem Gletscherlauf vom 17. September 1982, zeigt, dass über $95 \%$ des Sees auslaufen, eine Wassermenge von ungefähr $7 \mathrm{x}$ $10^{8} \mathrm{~m}^{3}$. Die Gletscherzunge, die den See abdämmt, bricht während eines Gletscherlaufes auseinander und sinkt zusammen, woraus sich schliessen lässt, dass der Auslaufmechanismus in der hydrostatischen Hebung des Eises aus einer subglazialen Abflussrinne besteht. Anzeichen am eisfreien Gletscherrand lassen vermuten, dass dieser Führungskanal im Felsbett ausgebildet ist. Grosse Schwankungen in der Periode der Wiederauffüllung des Strandline Lake lassen annehmen, dass die subglazialen Abflusstunnels bis zu einigen Jahren nach einem Gletscherlauf offen bleiben können, bevor sie durch Sedimente und/oder Gletschereis wieder verschlossen werden.
(Post and Mayo, 1971; personal communication from W.H. Mathews, 1982), has tunneled under its ice dam and flooded the Beluga River every 2 to 5 years for at least the past 25 years. Once a remote wilderness river, the Beluga River is now spanned by bridges and power lines leading to Anchorage, Alaska's largest city. The destructive consequences of jökulhlaups from Strandline Lake have greatly increased.

Based on our detailed study of the 1982 jökulhlaup, it appears that Strandline Lake drains when the ice which dams it is lifted enough to break the seal on a subglacial spillway and initiate a jökulhlaup. Long-range prediction of jökulhlaups can be based on the filling rate of the lake basin if the critical high-water level is known. However, the filling rate is so variable that closer monitoring would be necessary than is currently feasible for this remote lake. Therefore, we have attempted to identify a number of precursors of jökulhlaups which may be observed from aircraft or on satellite images. It appears that rapid iceberg calving from the glacier front which dams the lake and the filling of a number of small, marginal supraglacier pools indicate imminent drainage (Sturm and Benson, unpublished). 


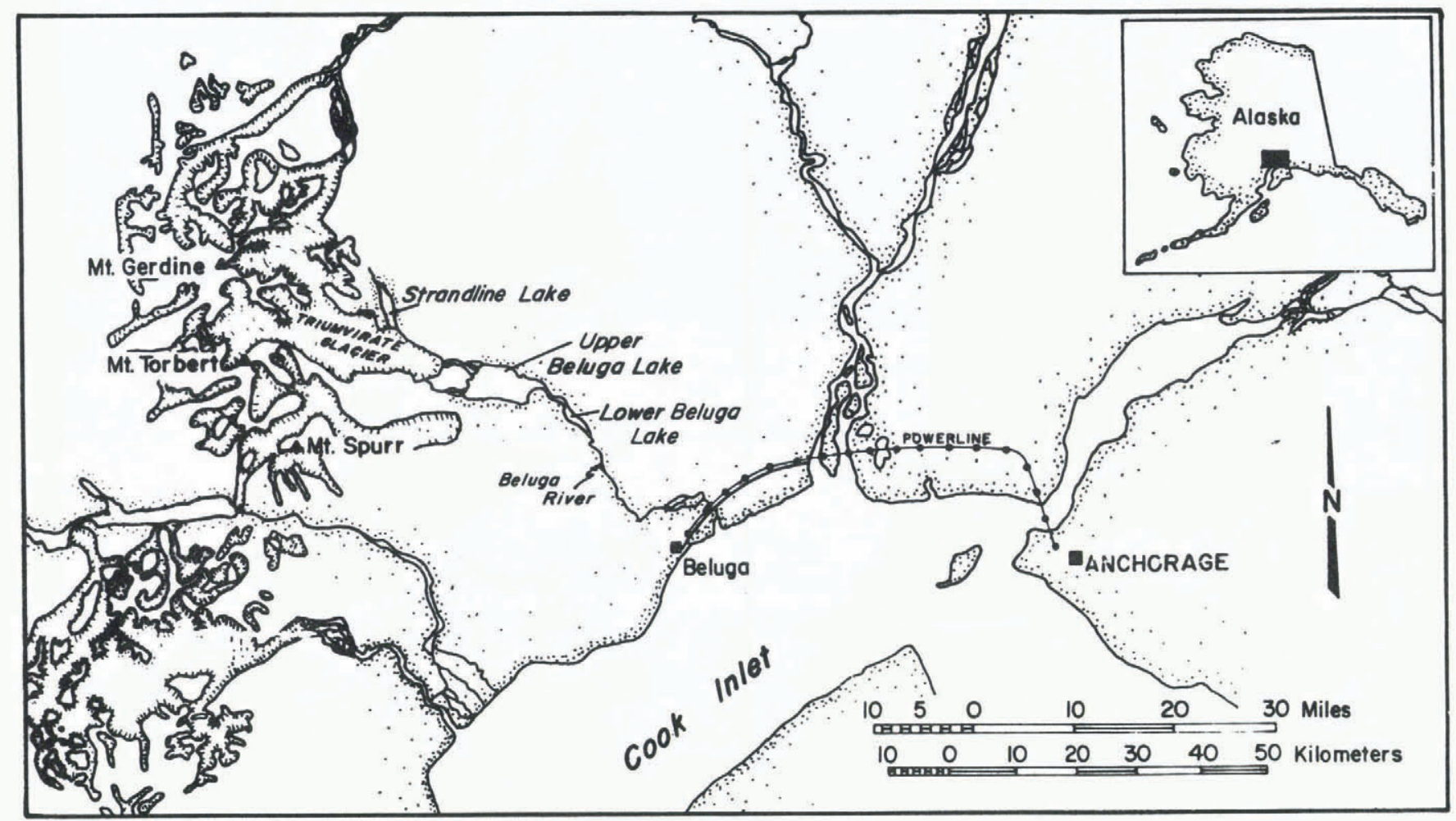

Fig. 1. A location map showing Strandline Lake, Upper and Lower Beluga Lakes, and their relationship to Triumvirate Glacier. The power line from the Beluga natural gas field to Anchorage crosses the Beluga River near its mouth.

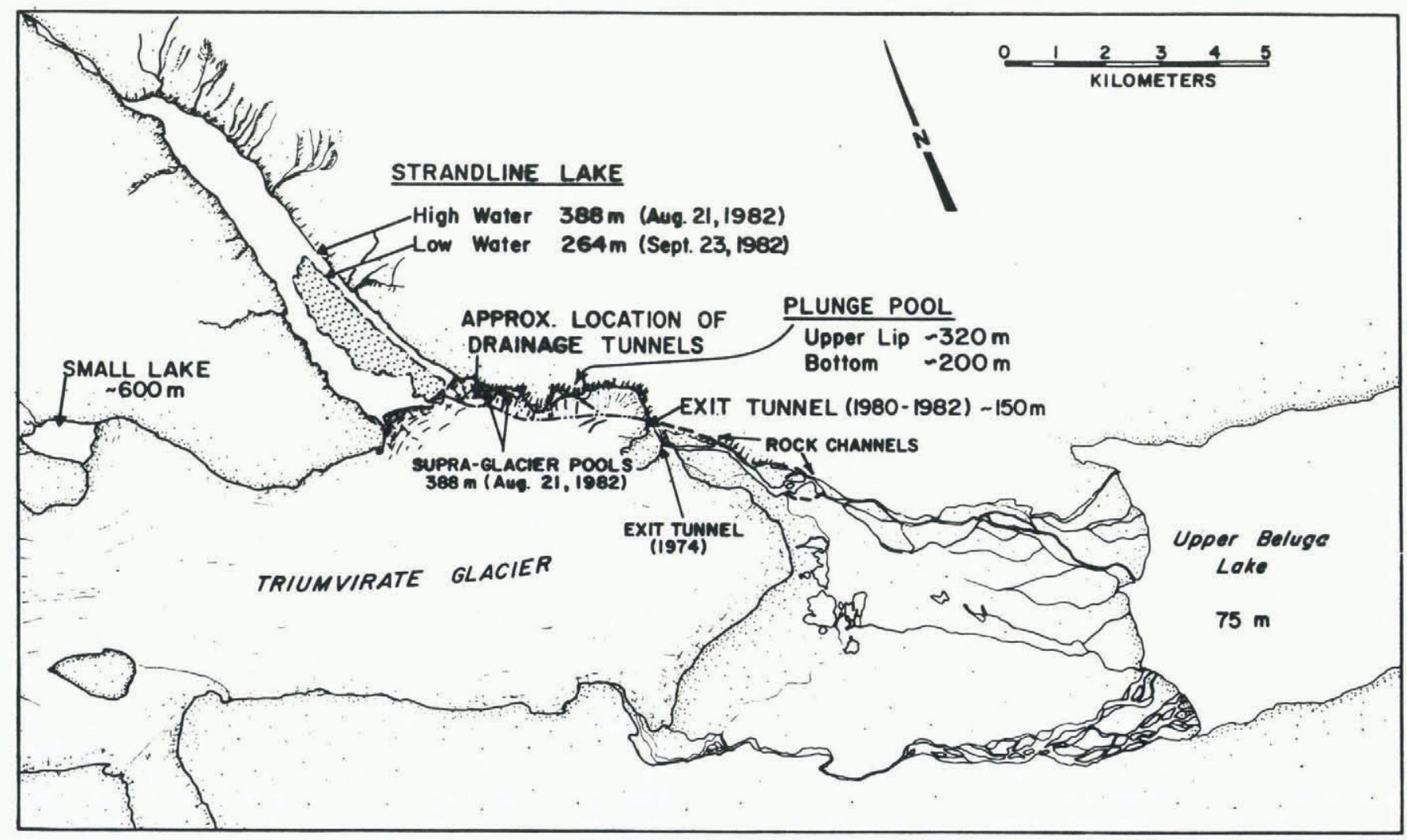

Fig. 2. Strandline Lake and Triumvirate Glacier, showing features along the jökulhlaup flood course. Abandoned channels cut in bedrock are shown by heavy dashed lines. Approximate locations of jökulhlaup tunnels are shown by dot-dash lines. 

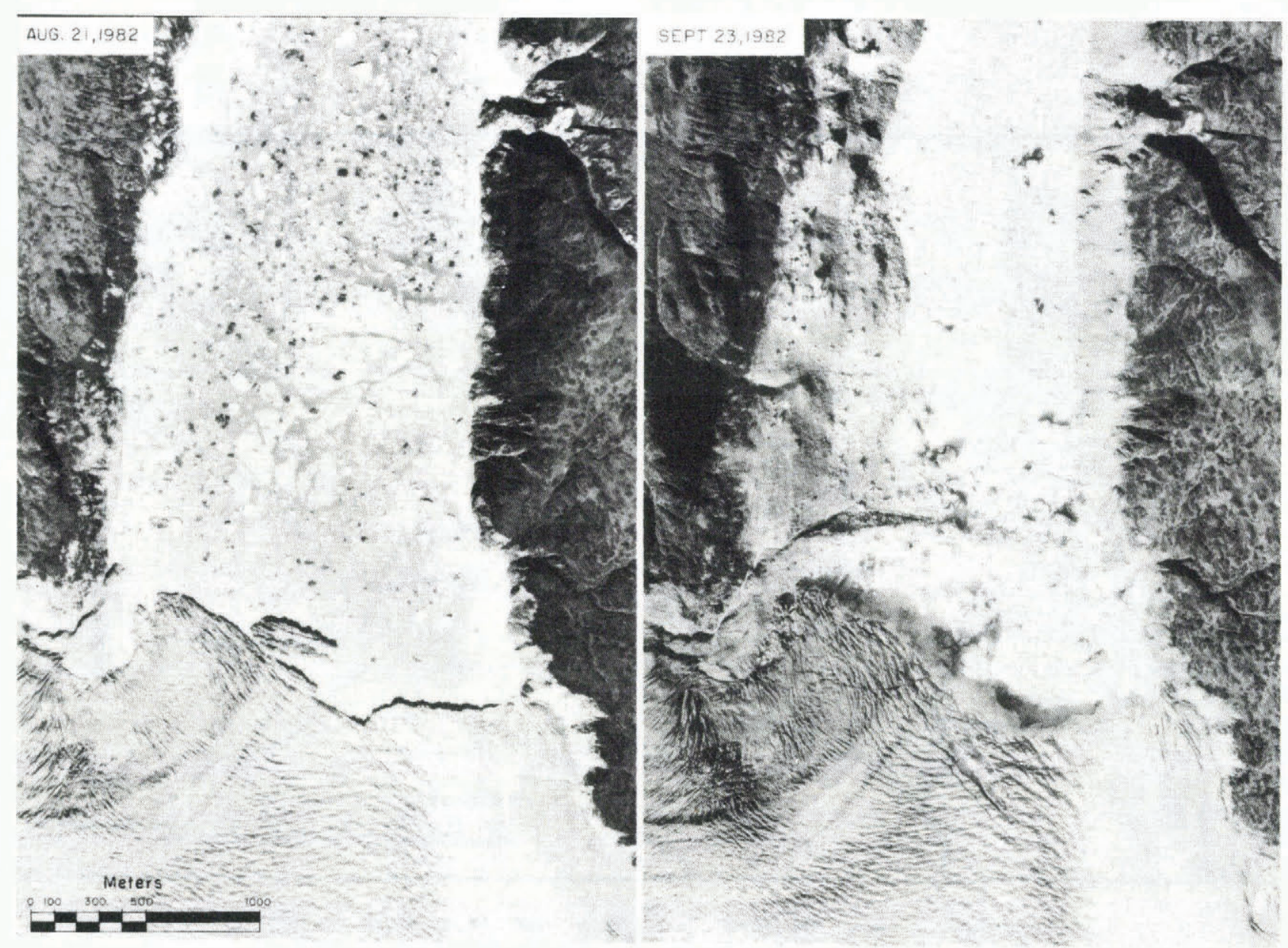

Fig. 3. Vertical aerial photographs taken 21 August 1982 and 23 September 1982. The jökulhlaup occurred on 17 September 1982. Largest stranded icebergs from 23 September 1982 were over $120 \mathrm{~m}$ high, which is consistent with the calculated glacier thickness (see text).

\section{THE STRANDLINE LAKE JÖKULHLAUP SYSTEM}

Strandline Lake occupies a steep-walled side valley near the terminus of Triumvirate Glacier in the Tordrillo Mountains, $120 \mathrm{~km}$ west of Anchorage (Fig. 1). Triumvirate Glacier descends eastward $30 \mathrm{~km}$ from Mount Spurr $(3374 \mathrm{~m})$. Near the terminus, a small lobe of ice flows northward about $0.4 \mathrm{~km}$ into a side valley and dams Strandline Lake (Figs 2 and 3 ). We refer to this lobe of Triumvirate Glacier as the "ice dam".

Jökulhlaups from Strandline Lake follow complex channels. Most of the drainage occurs in one or more subglacial tunnels but, during the early stages of each jökulhlaup, water flows along the margin of the glacier (Fig. 2). The marginal channel begins where water flows from under the ice at the supraglacier pools; it then follows the rock-ice margin until it drops over $100 \mathrm{~m}$ into a plunge pool cut in bedrock (labeled in Figure 2), where the water flows under the ice again. The upper lip of the plunge pool (about $320 \mathrm{~m}$ ) is well above the lowest level to which the lake drains. This subaerial course is abandoned when the final drainage of the lake takes place; at that time all of the flow is beneath the glacier. At the terminus, the waters emerge from a tunnel in the ice and flow $2 \mathrm{~km}$ through narrow rock canyon before spreading out over the outwash plains at the head of Beluga Lake.

Not only are the drainage channels complex but their locations are variable as well. One example is the variability in position of the exit tunnel at the terminus of the glacier; in 1982 it was $350 \mathrm{~m}$ from where it was in 1974 .

Multiple channels cut into bedrock (Fig. 2) have been exposed by the receding terminus of Triumvirate Glacier. In at least two places, V-shaped channels which have been cut more than $20 \mathrm{~m}$ into bedrock can be seen adjacent to but higher in elevation than the rock channel used during the 1982 jökulhlaup. The up-stream ends of these abandoned channels are truncated by more recent channels. During periods of time when Triumvirate Glacier was thicker and more advanced, these abandoned channels were subglacial and may have been formed by jökulhlaups. Complex bedrock configurations exist in the region of the ice dam and probably play a role in the drainage. The large supraglacier pool (Figs 2 and 5) forms immediately up-stream of a major rock bastion, and the ridge exposed at low water in front of the ice dam (Figs 3, 5, and 7) has outcrops of bedrock in addition to morainal material.

The jökulhlaup flood waters flow into Upper and Lower Beluga Lakes, which act as a natural flood-control system and mitigate destruction from the floods down-stream near Cook Inlet, where roadways, bridges, power lines, and gas and oil installations are located. For example, during the jökulhlaup of July 1979, the Beluga Lakes rose approximately $10 \mathrm{~m}$ in $40 \mathrm{~h}$ (personal communication from D. Witte, 1982). The combined surface area of the lakes is $4.9 \times 10^{7} \mathrm{~m}^{2}$. This indicates that about $5 \times 10^{8}$ $\mathrm{m}^{3}$ of flood water was temporarily stored in the lakes during the jökulhlaup. Simultaneously, however, the water level in Strandline Lake dropped more than $128 \mathrm{~m}$, which equals a water volume of $7 \times 10^{8} \mathrm{~m}^{3}$. Therefore, about two-thirds of the total 1979 jökulhlaup water was ponded temporarily in the Beluga Lakes and then discharged more slowly through the Beluga River; a flood crest of only $4.5 \mathrm{~m}$ was observed at the bridge $20 \mathrm{~km}$ down-stream from the Beluga Lakes. 
TABLE I

$\begin{array}{ccc}\text { Year Event } & \begin{array}{c}\text { Time since } \\ \text { last flood } \\ \text { (years) }\end{array} & \begin{array}{c}\text { Flood stage } \\ \text { Beluga River } \\ \text { bridge }\end{array}\end{array}$

～ $1940 \quad$ Flood ? ?

\section{8 \\ Destroyed old bridge}

$1 \mathrm{~m}$ below old bridge

Rose $4.3 \mathrm{~m}$ at new bridge
Calving bay with heavy iceberg concentrations in lake

Calving bay with heavy iceberg concentrations in lake

?

Increased calving; ice dam had calved back from its position in June

Heavy calving, from calving embayment and had calved back from previous position

\section{Heavy calving and large calving} embayment; marginal lakes full

Heavy calving and deep embayment; all marginal lakes full

Heavy calving and moderate embayment; all marginal lakes full
Source

"Beluga" Joe Sneller, recorded by E.P. Whittemore, 1978

USGS photographs $23 \mathrm{vv}$ 1370 PMG M

Walter Shultz, Anchorage Times, 15 July 1979, Vol. 65 , No. 194

Aerial photographs (oblique), Austin Post, USGS

Aerial photographs (verticals), Austin Post, USGS

Flood possible in 1970 based on its appearance on 2 Sep. No observations of the lake were recorded between 2 Sep. 1970 and 12 Jun. 1974

Aerial photographs (verticals), obtained from North Pacific Aerial Survey, Inc. (NPAS)

Oblique photographs, E.P. Whittemore

Oblique photographs, E.P. Whittemore

Oblique photographs, E.P. Whittemore

Aerial photogrammetry and field observations by authors

Aerial photogrammetry and field observations by authors

(?) Indicates large uncertainty.

* Dates indicate catastrophic stage of a longer event.

+ Note added in proof.

\section{FLOOD HISTORY}

A partial history of jökulhlaups from Strandline Lake is given in Table I. Before the development of gas and oil properties along the Beluga River in the 1960s, the effects of jokkulhlaups on the Beluga River attracted little notice. With the building of a bridge across the Beluga River, the situation changed, giving us a more complete account of floods from the years 1974, 1979, 1980, and 1982, including eye-witness accounts by F. Shomper in 1980 and 1982, by E. Whittemore in 1974, 1979, and 1980, and by D. Witte in 1979. Landsat imagery and aerial photography have been used to supplement this history but no information is available for floods before 1940 .

In 1984, Strandline Lake dumped again and we were able to observe the jokkulhlaups in greater detail than before. A report on these observations is being prepared.

\section{FLOOD PRECURSORS}

Strandline Lake derives its name from the prominent shorelines which mark former lake levels. These strandlines indicate that the lake's high-water stage has varied in altitude over $50 \mathrm{~m}$. However, from 1979 to 1982 the highwater altitude appears to have been approximately $388 \mathrm{~m} \pm$ $10 \mathrm{~m}$. If the present glacier thickness remains the same, this water level is an excellent indicator of imminent flooding.

The supraglacier pools of water located immediately down-glacier from the ice dam (Fig. 2) were observed to fill before the jökulhlaups of 1974, 1979, 1980, and 1982 (personal communication from E. Whittemore, 1982); we also observed them in 1984. A month before the 1982 jökulhlaup the water level in the pools was the same as in the lake. Because of the ice topography, the pools could not fill by lake water running over the ice surface. A subglacial hydraulic connection apparently exists between the pools and the lake. Furthermore, this connection appears to function only when the lake level is high, thus the filled pools act as readily visible precursors to a jökulhlaup. When the lake drained in 1979, 1980, and 1982, the pools were also drained and the ice below the pools had collapsed along fractures (Figs 5 and 6 ). The drainage path between the supraglacier pools and the plunge pool (Fig. 2) was abandoned before, or during, the subglacial drainage of the 


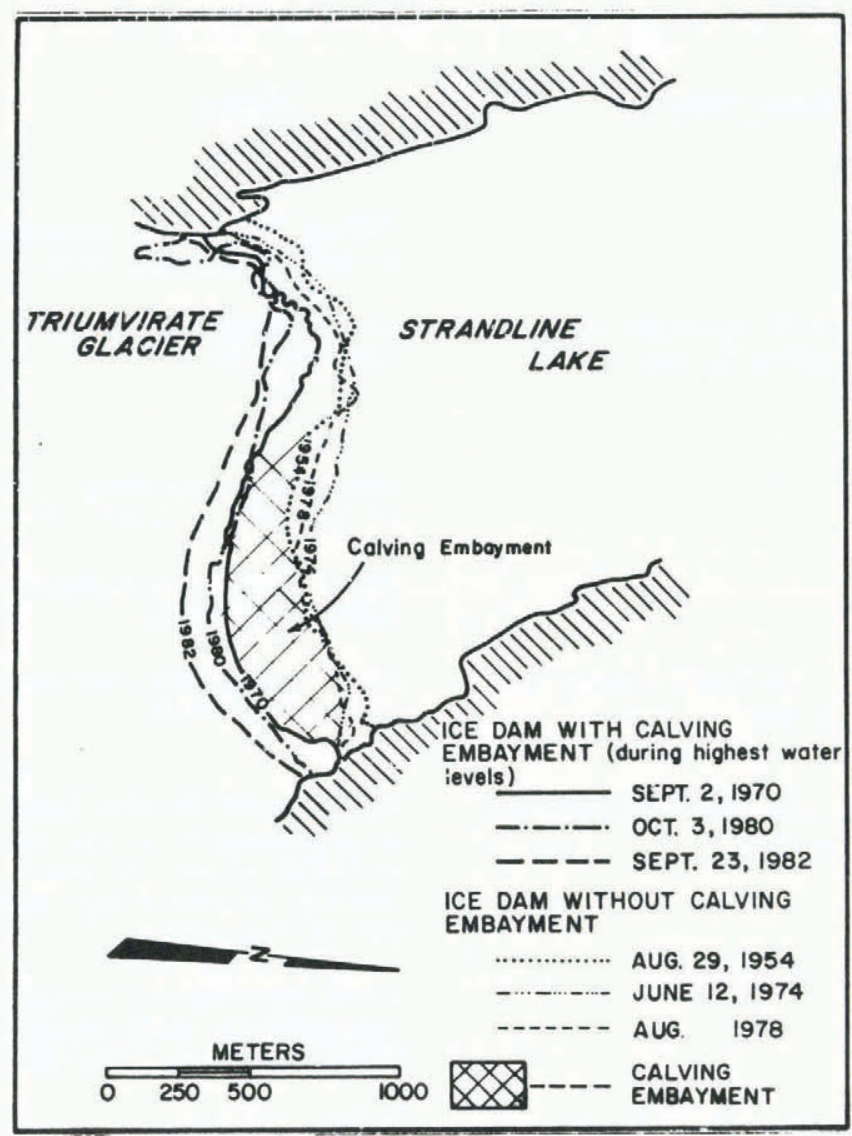

Fig. 4. The position of the ice dam of Triumvirate Glacier, showing the calving embayment which forms prior to a jökulhlaup. lake because its lowest point, the upper lip of the plunge pool $(320 \mathrm{~m})$, is too high to accomplish the final drainage.

The development of a calving embayment in the lobe of Triumvirate Glacier which dams Strandline Lake is the most useful precursor because it can be observed by aircraft and on satellite images (Miller, 1982). The lobe advances and retreats in a cycle determined by the filling of the lake. During periods when the lake is drained, the lobe has a positive mass balance and advances as much as $0.5 \mathrm{~km}$ into the lake basin. When the lake fills to a critical level, the lobe begins to float and calving increases. This results in a negative mass balance and a retreat of the terminus due to the formation of a calving embayment. Extensive calving chokes Strandline Lake with icebergs just before a jökulhlaup. The cycle repeats after a jökulhlaup has drained the lake. This cycle has been pieced together by examining over 56 Landsat images (12 of them enlarged to a scale of $1: 125000$ ), by examining numerous aerial photographs, and by talking with a number of long-term observers of the lake. Figure 4 shows a number of positions of the Triumvirate Glacier ice dam.

Although precursors can aid in short-term prediction of jökulhlaups, long-range prediction must be based, in part, on knowledge of the mechanisms which refill Strandline Lake. The lake fills from surface run-off from the glacier and the Strandline Lake watershed as well as from flow beneath Triumvirate Glacier. Discharge from either source is difficult to measure.

\section{JÖKULHLAUP OF 1982}

In August 1982, we were asked by Chugach Electric Company, whose main power transmission line crosses the Beluga River, for advice about potential flooding from Strandline Lake. Air and ground reconnaissance showed the lake filled to a high level and choked with ice. Flowering plants were found covered by water as deep as $2 \mathrm{~m}$. A large calving embayment extended $0.3 \mathrm{~km}$ into the ice dam

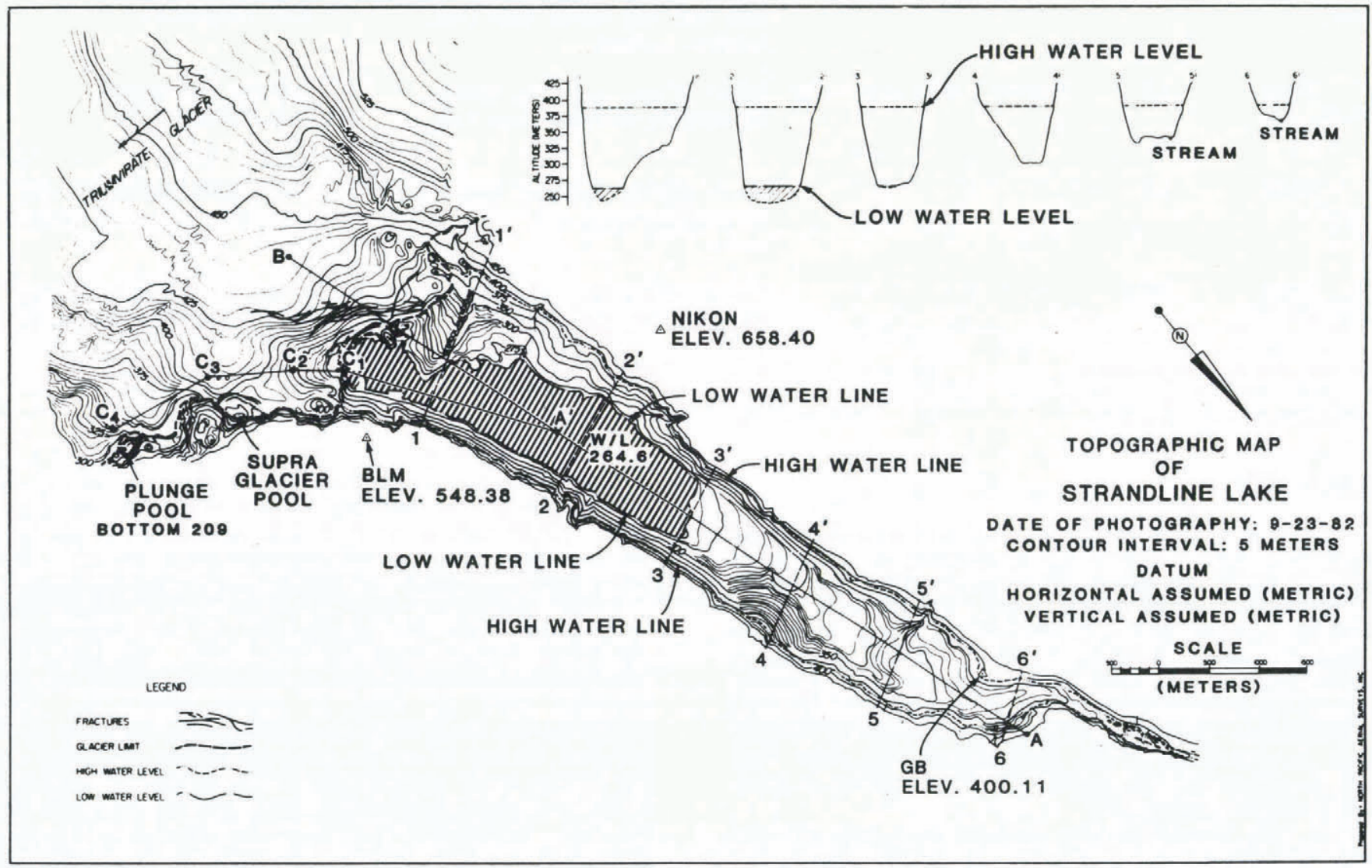

Fig. 5. Strandline Lake, showing the high-water level of 21 August 1982 and the low-water level of 23 September 1982. Cross-sections 1 through 6 (locations shown by dashed lines) show the lake bed, estimated where covered by water. The location of cross-sections $\mathrm{A}-\mathrm{A}^{\prime}-\mathrm{B}$ and $\mathrm{A}-\mathrm{A}^{\prime}-\mathrm{C}$ of Figure 7 are shown also. The cross-hatched area shows where ice has calved away before or during lake drainage. 


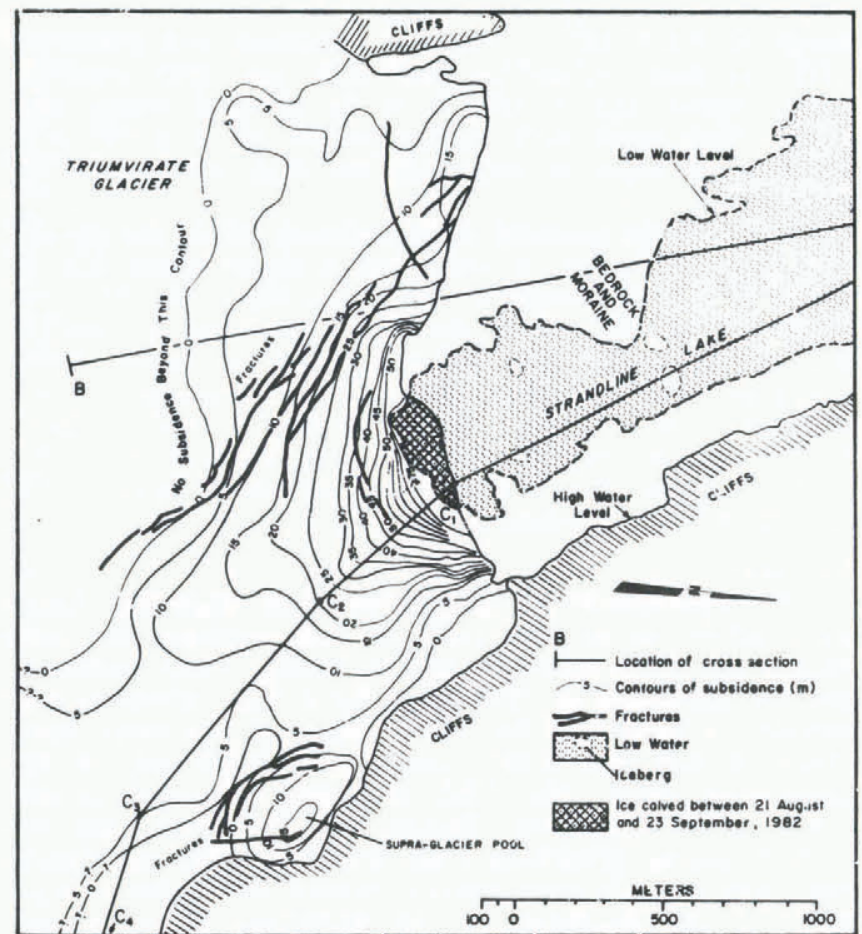

Fig. 6. Subsidence of the ice dam after drainage of the lake. This map was constructed by comparing the photogrammetrically determined topography before and after the jökulhlaup of 1982. The cross-hatched area represents the zone where ice has calved away. No contours are shown for subsidence of greater than $75 \mathrm{~m}$. Subsidence extends off this map but is $5 \mathrm{~m}$ or less and difficult to measure. and supraglacier pools were full. On the basis of these observations and the history of previous jökulhlaups, it was predicted that a jökulhlaup would occur soon (Sturm and Benson, unpublished). It culminted on 17 September 1982.

\section{Methods}

With a jökulhlaup clearly imminent, we contracted to have a set of vertical aerial photographs of Strandline Lake and Triumvirate Glacier taken on 21 August 1982, and a second set taken on 23 September 1982, 6 days after the event (Fig. 3). From the vertical photographs, photogrammetric maps at a scale of 1: 10000 with contour intervals of $5 \mathrm{~m}$ were constructed of the lake and ice dam before and after the lake drained. The water surface of 21 August 1982 was used as datum for photogrammetry, with an assumed altitude of $388 \mathrm{~m}$ which is approximately equivalent to the true altitude above sea-level. In comparing altitudes between the two maps, each was considered to be accurate to $\pm 2.5 \mathrm{~m}$. These maps have enabled us to measure the volume of the lake basin, to determine the amount of water which drained, and to make cross-sections of the glacier and lake before and after the jokulhlaup (Figs 5, 6, and 7). The cross-sections show the sagging of the ice dam which occurred after the jokulhlaup. Although we have no independent measurements of ice thickness, the photogrammetric analysis also yields estimates of ice thickness as discussed below. Other glacier-dammed lakes have been investigated by examining oblique aerial photographs (Post and Mayo, 1971) and by photogrammetry using vertical aerial photographs (Collins and Clarke, 1977). But, to our knowledge, detailed photogrammetric analysis of vertical aerial photographs, taken immediately before and after a jökulhlaup, has not been done.

\section{Volume of lake}

During the 1982 jobulhlaup the water level of the lake dropped from $388 \mathrm{~m}$ to $264 \mathrm{~m}$. The volume of the water which drained was calculated by measuring the areas of the lake basin at the upper and lower levels (388 and $264 \mathrm{~m}$ )
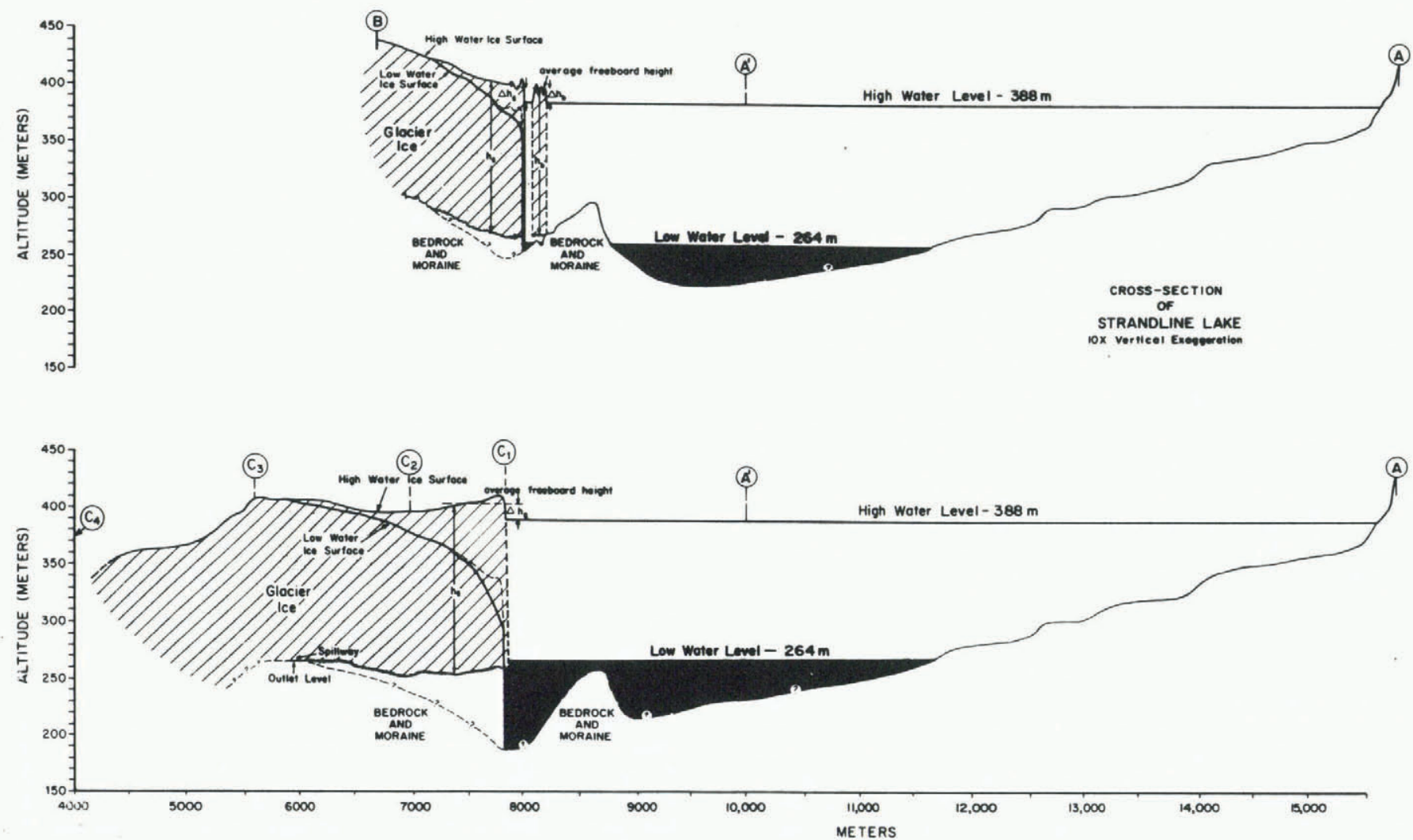

Fig. 7. Longitudinal cross-sections through Strandline Lake. Refer to Figures 5 and 6 for cross-section locations. Vertical exaggeration is $x 10$. Bed configuration and glacier bottom were drawn by using calculated ice thickness and reasonable approximations of lake-bottom profile, assuming the ice subsided until it rested on the bottom. 
and at the intermediate contours of $375,350,325,300$, and $275 \mathrm{~m}$. The volumes of the "slabs" of water between these altitudes were summed to give a total of $7.1 \times 10^{8} \mathrm{~m}^{3}$. This volume includes approximately $0.4 \times 10^{8} \mathrm{~m}^{3}$ of icebergs left stranded on the lake floor. After drainage, a residual amount of water, heavily ice-choked, remained in the lake basin. Based on cross-sections of the lake basin (Fig. 5), we estimated the volume of the residual water to be $0.2 \times 10^{8} \mathrm{~m}^{3}$, or less than $4 \%$ of the total lake volume. Therefore, about $95 \%$ of Strandline Lake drained during the jökulhlaup of 1982.

In 1984, we were able to observe the lake on the day after it drained and could see that its lowest water level was lower than in 1982 (when it was observed 6 days after drainage). This most likely means that the lake had begun to fill again before it was observed in 1982. At this time we simply take it as verification of our conclusion that the lake drained completely during the 1982 jökulhlaup.

\section{Changes in the Triumvirate Glacier ice dam}

The jökulhlaup of 1982 produced dramatic changes in the glacier which, indirectly, have been helpful in constructing the configuration of the subglacial drainage system. A trough-like depression more than $0.5 \mathrm{~km}$ wide formed between extensive fractures during the 1982 jökulhlaup. The amount of sagging into this depression has been mapped (Fig. 6) by comparing photogrammetric, topographic maps of the ice surface before and after the jökulhlaup. The zerosubsidence contour roughly coincides with the fracture zones. The fractures, which in some cases cut across existing crevasses, had widths exceeding $10 \mathrm{~m}$ and vertical displacements (normal faulting) exceeding $20 \mathrm{~m}$; large fracture-bound sections of the glacier were slumped and rotated. It seems probable that these fractures penetrated completely through the glacier to allow such displacement. In many cases, the fractures were water-filled immediately before the lake drained. This suggests that they connected with the lake water system. The fractures probably delineated the floating part of the glacier which took the form of a deep re-entrant with a calving bay at its outer edge. The re-entrant was aligned with the axis of the Strandline Lake valley and extended more than $1.0 \mathrm{~km}$ down-glacier; it included the area where supraglacier pools of water formed.

The volume displaced by sagging was calculated by measuring the areas enclosed by the sag contours in Figure 6. The volume displaced in the main trough-like depression was at least $30 \times 10^{6} \mathrm{~m}^{3}$. (This does not include $5.3 \times 10^{6}$ $\mathrm{m}^{3}$ of ice lost by calving nor the $0.6 \times 10^{6} \mathrm{~m}^{3}$ of sagging at the supraglacier pool.) There was more settling, of about $5 \mathrm{~m}$, farther down-glacier, in an area not covered on Figure 6 , but it is difficult to measure because the area is far from photogrammetric control. The displacement volume in this area is estimated to be $5 \times 10^{6} \mathrm{~m}^{3}$. Rather than include this estimate, we take it to strengthen our conclusion that the $30 \times 10^{6} \mathrm{~m}^{3}$ of sag in the more easily measured area of Figure 6 is a minimum value.

The volume displaced by sagging most likely represents lake water that was under the glacier before the jokulhlaup. It is approximately equal to our estimate of the volume of stranded icebergs in the drained lake, so that the volume of the lake water which drained is $7 \times 10^{8} \mathrm{~m}^{3}$. The potential energy released by this water as it drained out through the subglacial exit, $150 \mathrm{~m}$ above sea-level, was not adequate to melt a volume of ice equal to the volume of sagging. This can be shown by considering the available energy.

\section{Energy}

The energy dissipated within the glacier system during the 1982 jökulhlaup was calculated by considering the same volume elements used in calculating the lake volume above. The potential energy released as these volume elements drained through the glacier to the tunnel exit, $150 \mathrm{~m}$ above sea-level, summed to $13.1 \times 10^{14} \mathrm{~J}$. According to Mathews (1973), the amount of this potential energy that is transformed into kinetic energy represents only about $1.0 \%$ of the total. We have a report of a "rooster tail" which rose $10 \mathrm{~m}$ high as it exited the tunnel during the peak of the 1979 jökulhlaup. This suggests an exit velocity of $14 \mathrm{~m} \mathrm{~s}^{-1}$ during peak discharge. If we assume that half of the total water mass achieved this velocity, we obtain a kinetic energy of $0.3 \times 10^{14} \mathrm{~J}$, which is consistent with Mathews' (1973) estimate. Subtracting this from the total potential energy leaves $12.8 \times 10^{14} \mathrm{~J}$ to be released within the glacier. This could melt an ice volume of $4 \times 10^{6} \mathrm{~m}^{3}$, which is an order of magnitude less than the volume of sagging.

If all of the potential energy released within the glacier went into melting ice, it could melt a single tunnel with a radius of $18 \mathrm{~m}$ throughout the $4 \mathrm{~km}$ from the lake ice margin to the exit. Since the tunnel geometry is complex and several paths were followed, some of which were abandoned before the final drainage, it is reasonable to expect the primary drainage tunnel will have a similar radius. An exit tunnel with $10 \mathrm{~m}$ radius was observed after the 1984 jökulhlaup; this is a satisfying agreement between the observations and calculations.

\section{Discharge}

No hydrographs of jökulhlaups from Strandline Lake are available, so we must resort to crude estimates for discharge. D. Witte (personal communication, 1982) estimated that the jökulhlaup of 1979 lasted for 2 days. However, we consider it likely that the initial stages of the event went unnoticed and that Witte's observation applies only to its catastrophic stage. The 1982 jökulhlaup appeared to be approximately the same. During 1984 we were able to observe another jökulhlaup from Strandline Lake and found that more than 20 days elapsed between the initial leakage of water and completion of the jökulhlaup. If we assume that the events of 1979,1982 , and 1984 each spanned 20 days, their mean discharges were about $4 \times 10^{2} \mathrm{~m}^{3} \mathrm{~s}^{-1}$. But jökulhlaup discharges vary wildly and increase to peak values of short duration which are much greater than the mean values. The peak discharge, $Q_{\max }$, of 11 jökulhlaups was related empirically to the maximum lake volume, $V_{\max }$, by Clague and Mathews (1973) as follows:

$$
Q_{\max }=75\left(V_{\max } / 10^{6}\right)^{0.67} \text {. }
$$

By applying their formula to Strandline Lake, we obtain a peak discharge of $6.1 \times 10^{3} \mathrm{~m}^{3} \mathrm{~s}^{-1}$. In comparison, the Mississippi River at Vicksburg has a mean discharge of 15.5 x $10^{3} \mathrm{~m}^{3} \mathrm{~s}^{-1}$, and the Missouri River near St. Louis has a mean discharge of $2.0 \times 10^{3} \mathrm{~m}^{3} \mathrm{~s}^{-1}$.

\section{Ice thickness}

Although no independent measurements of glacier-ice thickness are available from ice-radar or seismic methods, we can estimate ice thickness and the configuration of the ice dam from the aerial photogrammetry. Two longitudinal cross-sections (Fig. 7) show water and ice conditions before and after the lake drained. Cross-section $A^{\prime}-B$ runs through a large, free-floating iceberg, newly separated from the glacier front. The iceberg is still upright and it must be free-floating to have moved away from the calving face. The average freeboard of the iceberg, $\Delta h_{\mathrm{b}}$, is $13 \mathrm{~m}$. For hydrostatic equilibrium,

$$
\text { where } \quad \begin{aligned}
\rho_{\mathrm{i}} g h_{\mathrm{b}} & =\rho_{\mathrm{w}} g\left(h_{\mathrm{b}}-\Delta h_{\mathrm{b}}\right) \\
\rho_{\mathrm{i}} & =\text { density of ice }=0.9 \mathrm{Mg} \mathrm{m}^{-3}, \\
\rho_{\mathrm{w}} & =\text { density of water }=1.0 \mathrm{Mg} \mathrm{m}, \\
h_{\mathrm{b}} & =\text { total iceberg thickness }(\mathrm{m}) .
\end{aligned}
$$

From this we calculate the iceberg thickness, $h_{\mathrm{b}}$, to be $130 \mathrm{~m}$. As shown in Figure 7, this would make the iceberg just barely grounded on the bedrock moraine ridge (Fig. 5) and explains why it has remained near the glacier face.

The glacier freeboard, $\Delta h_{\mathrm{g}}$, is equal to the iceberg freeboard, $\Delta h_{\mathrm{b}}$, along cross-section $\mathbf{A}^{\prime}-\mathrm{B}$. We assume that the glacier was afloat and that after the lake drained it rested directly on the bottom. This permits us to draw in the lake bottom along the cross-section. At the immediate ice face, slumping and fracturing has altered the glaciersurface profile where shown dashed in Figure 7. Close to cross-section $A^{\prime}-B$ the lake drained to expose the bottom and the ice thickness, measured where the entire ice cliff was exposed, is consistent with the flotation model. 


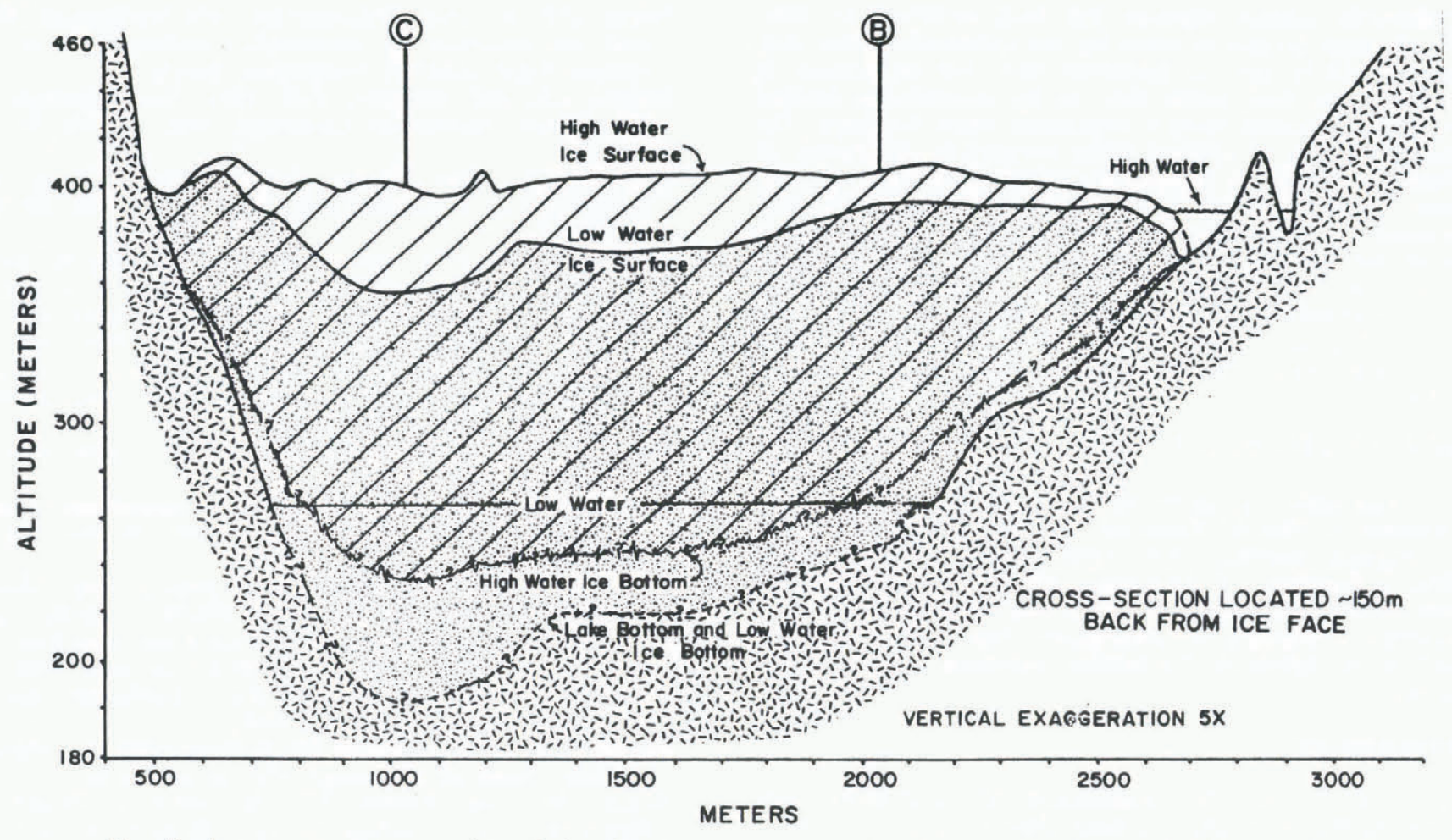

Fig. 8. A transverse cross-section of the floating ice shelf before and after the lake drained. The high-water glacier bottom was based on calculations of ice thickness. The lake-bottom profile was drawn so that ice subsidence was roughly equivalent to water thickness beneath the floating ice. The lake-bottom profile, approximated where not exposed, is also consistent with the transverse cross-sections shown in Figure 5.

We assume that the part of the glacier shown in crosssection $\mathbf{A}^{\prime}-C_{4}$ was also afloat before the lake drained; here the glacier freeboard, $\Delta h_{\mathrm{g}}$, was $14.5 \mathrm{~m}$ (Fig. 7). As would be expected, the ice is thicker here than at the edges. We suspect the subglacial spillway is along cross-section $\mathbf{A}^{\prime}-\mathbf{C}$, as it is the deepest part of the valley. The spillway should occur at the point where floating glacier ice is grounded; this coincides with the point of zero subsidence, approximately $1.0 \mathrm{~km}$ down-glacier.

A transverse profile of the glacier face both before and after the lake drained (Fig. 8) has been drawn to be consistent with the above arguments. Because of considerable slumping and fracturing at the immediate ice face, the profile was located $150 \mathrm{~m}$ back from the face. Using the freeboard of the ice to calculate ice thickness, we have drawn in the bottom of the floating ice. Using the amount of ice subsidence, we have drawn in the lake-bottom profile. The lake-bottom profile, including its asymmetry derived from the ice-subsidence values, is consistent with the observed lake-bottom profiles shown in Figure 5.

\section{DISCUSSION}

The overall mechanism which releases floods from Strandline Lake appears to be hydrostatic lifting of the ice dam when the lake fills to a critical level. The sagging and fracturing of the ice dam when the lake drains is consistent with this hydrostatic mechanism. With the buoyant support of the water removed, the previously floating ice collapses.

The critical seal between the rock and overlying ice is expected to lie along the track $A^{\prime}-C$ shown in Figure 7. This is the zone of minimum altitude of the ice surface before drainage and the zone of maximum subsidence after drainage. The grounding line of the ice before drainage can be located by the fractures and the zero-subsidence contour in Figure 6. Although the down-glacier point of zero subsidence is difficult to locate, we assume it lies near point $\mathrm{C}_{3}$ (Figs 5 and 7). The seal lies at an altitude no greater than $264 \mathrm{~m}$ (based on 1984 observations, it may be $20 \mathrm{~m}$ below this). The maximum ice pressure at the $264 \mathrm{~m}$ level at point $\mathrm{C}_{3}$ is 12.9 bar; the hydrostatic water pressure here would have been $12.2 \mathrm{bar}$, when the water level was $388 \mathrm{~m}$. This close agreement suggests that the mechanism for release of the jökulhlaups involves lifting the ice off of a critical seal. This in turn allows the flowing water to carve exit tunnels in the base of the glacier.

The post-drainage ice surface most likely reflects the shape of the bottom. It indicates a shoal near the grounding line, as has been observed in tide-water glaciers (Post, 1975; Powell, 1981). In a setting similar to Strandline Lake, Booth (in press) described valley-constricting embankments at the mouths of alpine valleys which were dammed by the Puget lobe of the Cordilleran ice sheet. However, the shoal under Triumvirate Glacier may involve complex bedrock configurations as well, just as does the ridge which is exposed when the water level is low (Figs 3,5, and 7). Recently deglaciated bedrock terrain along the glacier margin and terminus is deeply cut by stream channels and it is likely the glacier rests on similar terrain. Apparently, the controlling seal is in this shoal of bedrock and moraine at an altitude no greater than $264 \mathrm{~m}$.

Before the subglacial drainage system is fully established, complex flow along the glacier margin is observed. The supraglacier pools fill through subglacial hydraulic connections with the lake but, in the latter stages of a jökulhlaup, they collapse and connect with the main drainage tunnel system. The plunge pool (Fig. 2) is connected to the drainage system in the initial stages of the jökulhlaup but, when the lake level falls below $320 \mathrm{~m}$ (the upper lip of the plunge pool), it must cease to carry flood waters. These features are auxiliary to the main drainage tunnel system.

The release mechanism for jökulhlaups from Strandline Lake appears to be explained by hydrostatic lifting but the recharge of the lake is more complex. As Table I indicates, the lake has filled and discharged in as little as 1 year; it has also taken as long as 5 years (1974-79). Variation in the amount of annual precipitation is not sufficient to account for these variable filling rates. This suggests that the ice dam may not always reseal immediately after a jökulhlaup. For the entire period under discussion, the 
Triumvirate Glacier thickness has been sufficient to allow the drainage tunnels to reseal by ice deformation once they have ceased to carry a significant flow. For the tunnels to remain open, they either have to be mechanically bridged by boulders and/or carry a continuous water discharge. The complex system of channels being revealed by the retreat of Triumvirate Glacier is only one piece of evidence on the past history of this glacier-dammed lake system. The presence of strandlines $45 \mathrm{~m}$ above the 1982 high-water level indicates that past jokulhlaups were larger than the 1982 one. The volume of the lake corresponding to the highest strandline is approximately $12 \times 10^{8} \mathrm{~m}^{3}$ or $65 \%$ more than the 1982 volume. This suggests that some extremely large jökulhlaups have come from Strandline Lake.

\section{ACKNOWLEDGEMENTS}

This work was supported by the State of Alaska, Department of Natural Resources, Division of Geological and Geophysical Surveys, with field support from Chugach Electric Company of Anchorage, Alaska. Special thanks are due to E.P. Whittemore, D. Witte, and F. Shomper for their descriptive accounts of jökulhlaups from Strandline Lake, and to $\mathrm{H}$. Björnsson for helpful comments on the manuscript.

\section{REFERENCES}

Björnsson, Helgi. 1974. Explanation of jökulhlaups from Grimsvőtn, Vatnajökull, Iceland. Jökull, Ár 24, p. 1-26.

Björnsson, Helgi. 1976. Marginal and supraglacial lakes in Iceland. Jökull, Ár 26, p. 40-51.
Booth, D.B. In press. Sedimentation into ice-dammed lakes and the formation of ice-marginal embankments in the eastern Puget Lowland, Washington. Boreas.

Clague, J.J., and Mathews, W.H. 1973. The magnitude of jökulhlaups. Journal of Glaciology, Vol. 12, No. 66, p. 501-04.

Collins, S.G., and Clarke, G.K.C. 1977. History and bathymetry of a surge-dammed lake. Arctic, Vol. 30, No. 4, p. 217-24.

Mathews, W.H. 1973. Record of two jobkullhlaups. Union Géodésique et Géophysique Internationale. Association Internationale d'Hydrologie Scientifique. Commission de Neiges et Glaces. Symposium on the Hydrology of Glaciers, Cambridge, 7-13 September 1969, p. 99-110. (Publication No. 95 de l'Association Internationale d'Hydrologie Scientifique.)

Miller, J. 1982. Community Science Forum. Fairbanks News Miner, July 24 , p. B-2.

Nye, J.F. 1976. Water flow in glaciers: jökulhlaups, tunnels and veins. Journal of Glaciology, Vol. 17, No. 76, p. 181-207.

Post, A. 1975. Preliminary hydrography and historic terminal changes of Columbia Glacier, Alaska. U.S. Geological Survey. Hydrologic Investigations Atlas 559.

Post, A., and Mayo, L.R. 1971. Glacier dammed lakes and outburst floods in Alaska. U.S. Geological Survey. Hydrologic Investigations Atlas 455.

Powell, R.D. 1981. A model for sedimentation by tidewater glaciers. Annals of Glaciology, Vol. 2, p. 129-34.

Sturm, M., and Benson, C.S. Unpublished. Report on Strandline Lake flooding hazard. Report submitted to Chugach Electric Company, Anchorage, Alaska. Fairbanks, Alaska, University of Alaska. Geophysical Institute. 